\title{
Gallbladder Goblet Cell Carcinoid
}

National Cancer Institute

\section{Source}

National Cancer Institute. Gallbladder Goblet Cell Carcinoid. NCI Thesaurus. Code C96928.

An invasive mixed adenoneuroendocrine carcinoma of the gallbladder characterized by

the presence of neoplastic signet-ring cells resembling goblet cells of the intestine. 